"TURYZM" 1995 , t. 5 , z. 2

\title{
Wlodzimierz Kurek
}

\section{BIBLIOGRAFIA PRAC PROFESOR JADWIGI WARSZYŃSKIEJ} LA BIBLIOGRAPHIE DES TRAVAUX DU PROFESSEUR JADWIGA
WARSZYŃSKA THE BIBLIOGRAPHY OF PROFESSOR JADWIGA WARSZYŃSKA'S
WORKS

\section{Monografie, studia i rozprawy}

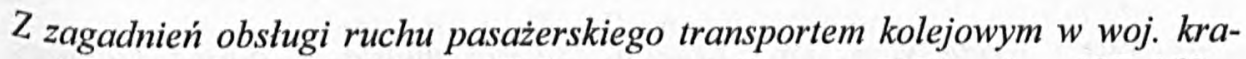
kowskim, Zeszyty Naukowe UJ, Prace Geogr. Ekonom. 1959, z. 1, s. 137-169.

Zaopatrzenie miasta Krakowa $w$ mleko, na tle bazy surowcowej oraz produkcji przemyslu mleczarskiego $w$ woj. krakowskim, Zeszyty Naukowe UJ, Prace Geogr. 1961, z. 4, s. 117-164.

Transport drogowy w woj. krakowskim, Zeszyty Naukowe UJ, Prace Geogr. 1963 , z. 6, s. 101-134.

Ze studiów nad zdjęciem użytkowania zachodniej części pow. olkuskiego, Problemy Ekonomiczne 1964, s. 64-87 (współaut.: A. Iwińska).

Struktura ekonomiczna i powiqzania przestrzenne Krakowa $w$ świetle przewozów towarowych, Biul. KPZK PAN 1967, z. 44, s. 37-111 (współaut.: B. Kortus).

$Z$ problemów geografii turyzmu na Węgrzech, Zeszyty Naukowe UJ, Prace Geogr. 1967, z. 15, s. 113-135.

Analiza natężenia i rozkladu ruchu pojazdów $w$ czasie na drogach węzta tarnowskiego, Zeszyty Naukowe UJ, Prace Geogr. 1968, z. 20, s. 123-130.

Krakowski węzet komunikacyjny, Folia Geogr., Ser. Geogr.-Oeconom. 1968, vol. 1, s. 117-139. 
Kraków jako ośrodek turystyczny, Folia Geogr., Ser. Geogr.-Oeconom. 1968, vol. 1, s. 141-167.

Przewozy towarowe jako kryterium regionalizacji ekonomicznej, Zeszyty Naukowe UJ, Prace Geogr. 1969, z. 22, s. 59-103.

Analiza ruchu drogowego na arteriach wylotowych m. Tarnowa, Folia Geogr., Ser. Geogr.-Oeconom. 1969, vol. 2, s. 105-123.

Baza turystyczna i jej wykorzystanie w rejonie krakowskim w 1968 r., Statystyka Regionalna, Kraków 1969, WUS, ss. 50 (współaut.: A. Jackowski).

Metodyka badań statystycznych ruchu turystyczno-wypoczynkowego $i$ zwiqzanych z nim dziedzin życia gospodarczego, Kraków 1969, WUS, ss. 50 (współaut.: A. Jackowski, J. Bukowski).

Waloryzacja miejscowości z punktu widzenia atrakcyjności turystycznej, Zeszyty Naukowe UJ, Prace Geogr. 1970, z. 27, s. 103-114.

Komunikacja, [w:] Kraków. Rozwój miasta w Polsce Ludowej, Warszawa 1971, s. $162-187$.

Handel i uslugi, [w:] Kraków. Rozwój miasta w Polsce Ludowej, Warszawa 1971, s. 188-203.

Turystyka i wypoczynek, [w:] Kraków. Rozwój miasta w Polsce Ludowej, Warszawa 1971, s. 234-253.

Rola i funkcje Tarnowa w świetle przewozów towarowych, Prace Geogr. IG PAN 1971, nr 82, s. 125-142.

Waloryzacja miejscowości powiatu żywieckiego z punktu widzenia atrakcyjności turystycznej, Folia Geogr., Ser. Geogr.-Oeconom. 1971, vol. 4, s. 113-136.

Turystyka w regionie krakowskim, Nauka dla Wszystkich, nr 152, PAN, Kraków 1971, ss. 41 (współaut.: A. Jackowski).

Ocena walorów turystycznych miejscowości polożonych w dorzeczu Bialej Dunajcowej, Folia Geogr., Ser. Geogr.-Oeconom. 1972, vol. 5, s. 121-148.

Ocena środowiska naturalnego pow. żywieckiego pod względem sezonowości i form ruchu turystycznego, Czas. Geogr. 1972, t. 43, z. 2, s. 171-190.

Ruch turystyczny w Tatrach, Czas. Geogr. 1974, t. 45, z. 1, s. 131-144.

Ocena zasobów środowiska naturalnego dla potrzeb turystyki (na przykladzie woj. krakowskiego), Zeszyty Naukowe UJ, Prace Geogr. 1974, z. 36, ss.143.

Turystyka $w$ Makroregionie Poludniowym, Studia nad Ekonomiką Regionu 1974, z. 5, s. 280-295 (współaut.: A. Jackowski).

Handel $i$ uslugi, Folia Geogr., Ser. Geogr.-Oeconom. 1975, vol. 8, s. 117-131. 
Komunikacja, Folia Geogr., Ser. Geogr.-Oeconom. 1975, vol. 8, s. 95-116.

Turystyka, Folia Geogr., Ser. Geogr.-Oeconom. 1975, vol. 8, s. 133-150.

An evaluation of the resources of the natural environment for tourism and recreation, Geogr. Polon. 1976, z. 34, s. 255-264.

Atrakcyjność dorzecza Biatej Dunajcowej dla turystyki, Studia Ośrodka Dokument. Fizjogr., Kraków 1976, t. 5, s. 333-368.

Evaluation of tourist attractiveness of the natural environment for the needs of holiday recreation, Zeszyty Nauk. UJ, Prace Geogr. 1976, z. 43, s. 163-176.

Węgry, [w:] Slownik geografii Europy, Warszawa 1976, Wiedza Powszechna, s. $450-463$.

Miejskie województwo krakowskie jako zaplecze rekreacyjne Krakowa, Folia Geogr., Ser. Geogr.-Oeconom. 1978, vol. 11, s. 87-105.

Funkcja uzdrowiskowa i turystyczna regionu muszyńskiego, [w:] Sqdecczyzna Poludniowo-Wschodnia, t. 2, Problemy gospodarki wspólczesnej, Kraków 1979, s. 149-193 (współaut.: A. Jackowski).

Ocena zasobów turystycznych środowiska naturalnego dla potrzeb planowania regionalnego, Monografia AWF w Poznaniu 1979, nr 116, s. 121-127.

Uklad przestrzenny i funkcje komunikacji (w woj. miejskim krakowskim), Folia Geogr., Ser. Geogr.-Oeconom. 1979, vol. 12, s. 93-105 (współaut.: M. Kozanecka).

Wybrane zagadnienia z geografii turyzmu (woj. miejskiego krakowskiego), Folia Geogr., Ser. Geogr.-Oeconom. 1979, vol. 12, s. 107-121 (współaut.: A. Jackowski).

The application of the simulation method "Monte Carlo" to forecast spatial distribution of tourist movement, Folia Geogr., Ser. Geogr.-Oeconom. 1980, vol. 13, s. 73-84.

Atrakcyjność turystyczna środowiska naturalnego miejscowości woj. bielskiego, Studia nad Ekonomiką Regionu 1981, t. 11, s. 120-142.

Walory turystyczne miejscowości polożonych $w$ otoczeniu sztucznych zbiorników wodnych rożnowskiego i czchowskiego, Problemy Zagosp. Ziem Górskich 1981 , z. 21 , s. 227-248.

Tourist Travel in the Tatra Mountains, Frankfurt Wirtschafts und Sozialgeographische Schriften 1982, II. 41, s. 57-66.

Wplyw realizacji programu ,Wista” na zmiany w organizacji przestrzennej turystyki w Dorzeczu Górnej Wisty (DGW), Zeszyty TUP 1982, nr 119, s. 218-244. 
Problems of Tourism in the Urban Voivodship of Cracow, [w:] Tourism and Recreation in the Surroundings of Big Towns, Sympozjum, Łódź 1983, s. 44-65 (współaut.: A. Jackowski).

Changements spatiaux des attraits touristiques du bassin de la Haute-Vistula resultant de la realisation du project „Wista”, [w:] Colloque de la Commission de Geographie du Tourisme et des Loisirs (Lipari 20-25/9/1982), t. 2, Messina 1984, s. 464-471.

Wybrane zagadnienia z geografii turyzmu woj. bielskiego, Folia Geogr. 1984, vol. 16, s. 122-140.

Prognosis of Tourist Traffic to Cracow for Spatial Planning Purposes, Published on the occasion of the 25th Congress of International Geographical Union in Paris, 1984, Zeszyty Naukowe UJ, Prace Geogr. 1984, z. 60, s. 93-96.

Cartographie touristique en Pologne, IGU Commission, Geography of Tourism and Leisure, Sub. - Commission - Cartography, Department of Economic Geography and Regional Planning at the University of Bayreuth, 1984, s. 1-8.

Geography of Tourism in Poland, GeoJournal 1984, 9/1, by D. Reidel Publishing Comp.

Funkcja turystyczna Karpat Polskich, Folia Geogr., Ser. Geogr.-Oeconom. 1985, vol. 18, s. 79-104.

Wplyw budowli wodnych na zmiany atrakcyjności turystycznej dorzecza (na przykladzie dorzecza górnej Wisly), Monografie AWF w Poznaniu 1985, nr 209, s. 189-199.

Problemy badawcze geografii turyzmu, Folia Geogr., Ser. Geogr.-Oeconom. 1986, vol. 19, s. 59-65.

Studies on the Geography of Tourism, Annals of Tourism Research 1986, vol. 13, Pergamon Press INC, s. 655-658 (współaut.: A. Jackowski).

Przyrodnicze uwarunkowania rozwoju turystycznych form rekreacji w strefie wyżynnej $i$ górskiej, [w:] Wplyw środowiska przyrodniczego na zróżnicowanie turystycznych form rekreacji, Warszawa 1986, AWF, s. 198-220 (współaut.: A. Koliba, K. Mularz, E. Środoń).

Przydatność środowiska przyrodniczego GOP dla rozwoju turystycznych form rekreacji, [w:] Wplyw środowiska przyrodniczego na zróżnicowanie turystycznych form rekreacji, Warszawa 1986, AWF, s. 131-156 (współaut.: A. Jackowski, J. Groch, W. Kurek, A. Koliba, K. Mularz, E. Szumera).

Rozwój badań z zakresu geografii turyzmu $w$ ośrodku krakowskim $w$ latach 1945-1985, Folia Geogr., Ser. Geogr.-Oeconom. 1987, vol. 20, s. 95-110 (współaut.: A. Jackowski). 
Turystyka, [w:] Województwo tarnowskie. Monografia, Wrocław 1988, Ossolineum, s. 289-309.

Struktura funkcjonalna i powiqzania przestrzenne, [w:] Województwo tarnowskie. Monografia, Wrocław 1988, Ossolineum, s. 309-317.

Tourist Function of Polish Carpathians, [w:] Carpathian Tourist Conference, Zeszyty Naukowe UJ, Prace Geogr. 1989, z. 80 (red. zeszytu).

Eine Modellmethode zur Bewertung der Umwelt fur Erholungszwecke (am Beispiel der Vorstadtzone Krakaus), Bochumer Geographische Arbeiten 1989, Heft 51, Paderborn.

Ruch turystyczny w Zakopanem po drugiej wojnie światowej, [w:] Zakopane czterysta lat dziejów (pod red. D. Dutkowej), Kraków 1991, KAW.

Turystyka, [w:] Dorzecze Górnej Wisty, Cz. 1 (pod red. I. Dynowskiej i M. Maciejewskiego), Warszawa-Kraków 1991, PWN.

Funkcje spoleczno-gospodarcze, [w:] Dorzecze Górnej Wisty, Cz. 1 (pod red. I. Dynowskiej i M. Maciejewskiego), Warszawa-Kraków 1991, PWN.

Research Problems of the Geography of Tourism, [w:] Scientific and Didactic Activity in Polish University Centres on the Geography of Tourism, Published on the Occasion of the 27th Congress of International Geographical Union in Washington 1992., Zeszyty Naukowe UJ, Prace Geogr. 1992, z. 86 (red. zeszytu).

Geografia turyzmu w Instytucie Geografii Uniwersytetu Jagiellońskiego po drugiej wojnie światowej, Zeszyty Naukowe UJ, Prace Geogr. 1992, z. 89.

Cracow as the Centre of Tourist Traffic, Turyzm 1992, z. 1.

Karpaty polskie - przyroda, czlowiek i jego dzialalność (redakcja książki), Kraków 1995.

\section{Referaty i komunikaty}

Przewozy towarowe jako kryterium regionalizacji ekonomicznej. (Próba metody na przykladzie Polski Poludniowej), Sprawozdania z posiedzeń Kom. Nauk. Oddz. PAN w Krakowie, styczeń-czerwiec 1967, s. 346-348.

Krakowski węzel kolejowy $i$ drogowy, Sprawozdania z posiedzeń Kom. Nauk. Oddz. PAN w Krakowie, lipiec - grudzień 1967, s. 758-759.

Wybrane zagadnienia z geografii turystycznej miasta Krakowa, Sprawozdania z posiedzeń Kom. Nauk. Oddz. PAN w Krakowie, lipiec-grudzień 1968, s. $760-761$. 
$Z$ badań nad ruchem $w$ tarnowskim weźle drogowym, Sprawozdania z posiedzeń Kom. Nauk. Oddz. PAN w Krakowie, styczeń-czerwiec 1968, s. 239-240.

Przewodnik wycieczki po Wyżynie Krakowsko-Miechowskiej, Kraków 1972, PTG, ss.19 (współaut.: I. Dynowska i J. Pokorny).

Kartograficzny obraz turystyki woj. krakowskiego, [w:] Problemy kartografii turystycznej, Kraków-Warszawa 1973, s. 39-43 (współaut.: A. Jackowski).

An evalution of natural environment resources for the development of tourist functions, [w:] Simpozium geograwski problemi po inspolzuvanie na kurortnija potencial, Warna-Drużba, 20-21 X 1973, Warna 1973.

Ocena zasobów turystycznych środowiska naturalnego dla turystyki zagranicznej, [w:] Problemy turystyki zagranicznej, Materiały z Sympozjum Naukowego w Stulecie Zorganizowanej Turystyki Polskiej, Zakopane, 19-21 X 1973, Kraków 1974, s. 213-216.

Międzynarodowe Sympozjum z Geografii Turyzmu, Biuletyn Informacyjny 1974, Instytut Turystyki, nr 8/9, s. 67-68 (współaut.: A. Jackowski).

L'attrait pour le tourisme des loisirs comme fonction de la distance et des ressources touristique du milieu, [w:] Geography of Tourism and Recreation, XXIII International Geographical Congress, Moskwa 1976, s. 98-101.

Ocena zasobów środowiska naturalnego dla potrzeb turystyki, Dokumentacja Geogr. 1976, z. 1, s. 102-105.

L'attrait touristique du milieu naturel et le développment de la fonction touristique au niveau de la localité et de la région, [w:] Zagadnienia terminologii w geografii turyzmu, Kraków 1976, s. 64-69 (współaut.: A. Jackowski).

Le tourisme comme l'object des recherches de la géographie du tourisme, [w:] Zagadnienia terminologii w geografii turyzmu, Kraków 1976, s. 69-73 (współaut.: A. Jackowski).

Méthode á modéle pour l'evaluation des réserves du milieu naturel disponibles pour les besoins du tourisme, [w:] Actes du $\sigma^{e}$ Congréss International de Spéléologie, Praha 1977, t. 7, s. 333-336.

Impact of passport facilities in the passenger traffic between Poland and German Democr. (GDR) on the development of touristic phenomena, Frankfurter Wirtschafts- und Sozialgeographische Schriften 1979, Heft 31, s. 353 (współaut.: A. Jackowski).

Ocenka resursov estestvennoj sredy dlja potrebnostei turizma, [w:] Geografski problemi po izpolzuvane na Kurortnija potencial, Sofija 1979, s. 152-156.

Provision for recreation within the conurbation of the Upper Silesian Industrial District (GOP), Wiener Georgaphische Schriften 53/54, Beiträge zur Frem- 
denverkehrsgeographie, 2 Teil, Wien 1979, s. 159-161 (współaut.: A. Jackowski).

Tourist Travel in the Tatra Mountains, 24th International Geographical Congres, Tokio 1980, Working group meeting in Nagano.

Prognozowanie rozkladu przestrzennego ruchu turystycznego przy pomocy metody symulacyjnej „Monte Carlo”, [w:] Seminarium Czesko-Polskie, Ostrawa-Morawka, Sbornik Československé geografické společnosti 1981, R. 86.

Zmiany przestrzenne $w$ atrakcyjności turystycznej dorzecza górnej Wisly $w$ wyniku realizacji programu „Wisla”, Materiały Zjazdu Geografów Polskich, Toruń 1983 (współaut.: A. Koliba).

Tourist Traffic to Polyfunctional Cities, 25th Congress International de Geographie, Paris 27-31 VIII 1984.

Le developpement du turisme a Cracovie, [w:] Grosstadt-tourismus, Berlin 1986, Dietrich Reimer Verlag, s. 213-215, Union Géographique Internationale Commission de Géographie du Tourisme et des Loisirs (współaut.: A. Jackowski).

Problemy rozwoju turystyki $w$ woj. bielskim, [w:] Sbornik referátu z ćeskoslovensko-polské geografické konference $k$ problematice prostredi (Térlicko 1985), 1986, Pedagogická fakulta v Ostravé, s. 33-41.

\section{Podręczniki}

Podstawy geografii turyzmu, Warszawa 1978, PWN, ss. 333, dodruk, Warszawa 1979, PWN, ss. 337 (współaut.: A. Jackowski).

rec. M. Gúčik [w:] Ekonomická Revue Cestovného Ruchu, nr 3, Vládny Vybór pre Cestowny Ruch SSR, Bratislava, 1980.

Z. Mieczkowski, Synthetic Studies on Geography of Tourism in Eastern Europe, Geographical Survey 1979 , vol. 8 , no. 3 .

Regionalna geografia turystyczna świata. Cz. II, Kraje pozaeuropejskie, redakcja i autorstwo: Syria, Liban, Izrael, Jordania, Skrypty Uczelniane UJ $1988, \mathrm{nr} 578$.

Regionalna geografia turystyczna świata. Cz. I, Europa i ZSRR, redakcja i autorstwo: Albania, Grecja (współaut.: J. Jemioła), Szwajcaria, Liechtenstein, Austria, RFN, NRD, Berlin Zachodni, Czechoslowacja, Węgry, Rumunia, Skrypty Uczelniane UJ 1990, nr 631.

Geografia turystyczna świata. Cz. 1, redakcja i autorstwo: Albania, Grecja (współaut.: J. Jemioła), Rumunia, Szwajcaria, Liechtenstein, Austria, Niem- 
cy, Polska (współaut.: A. Jackowski), Czechy, Slowacja, Węgry, Warszawa 1994, PWN.

Geografia turystyczna świata. Cz. 2, redakcja książki i autorstwo: Syria, Liban, Izrael, Jordania, Jemen (współaut:. J. Jemioła), Warszawa 1995, PWN.

Dr Włodzimierz Kurek

Instytut Geografii

Wplynęlo:

Uniwersytet Jagielloński

21 października $1995 \mathrm{r}$.

ul. Grodzka 64

31-044 Kraków 